\title{
Ecological Risk Assessment of Cadmium in Karst Lake Sediments Based on Daphnia pulex Ecotoxicology
}

\author{
Faustino Dinis ${ }^{1}{ }^{(}$, Hongyan Liu ${ }^{1,2,3, *} \mathbb{C}$, Qingdong Liu ${ }^{1}$, Xuewen Wang ${ }^{1}$ and Meng $\mathrm{Xu}^{2}$ \\ 1 College of Agriculture, Guizhou University, Guiyang 550025, China; faustinodinisvfm200@gmail.com (F.D.); \\ liuqingwe@gmail.com (Q.L.); wxwzhhaa@gmail.com (X.W.) \\ 2 College of Resources and Environmental Engineering, Guizhou University, Guiyang 550025, China; \\ mengxu192@gmail.com \\ 3 Key laboratory of Karst Georesources and Environment, Guizhou University, Ministry of Education, \\ Guiyang 550025, China \\ * Correspondence: hyliu@gzu.edu.cn
}

Citation: Dinis, F.; Liu, H.; Liu, Q.; Wang, X.; Xu, M. Ecological Risk Assessment of Cadmium in Karst Lake Sediments Based on Daphnia pulex Ecotoxicology. Minerals 2021, 11, 650. https://doi.org/10.3390/ $\min 11060650$

Academic Editors:

Ana Romero-Freire and Hao Qiu

Received: 4 May 2021

Accepted: 13 June 2021

Published: 18 June 2021

Publisher's Note: MDPI stays neutral with regard to jurisdictional claims in published maps and institutional affiliations.

Copyright: () 2021 by the authors. Licensee MDPI, Basel, Switzerland. This article is an open access article distributed under the terms and conditions of the Creative Commons Attribution (CC BY) license (https:// creativecommons.org/licenses/by/ $4.0 /)$.

\begin{abstract}
The background value of cadmium (Cd) in soil and water sediments in the karst area is $0.31 \mathrm{mg} \mathrm{kg}^{-1}$, with a typical high background of cadmium geochemistry. It is well-known that $\mathrm{Cd}$ is classified as a highly toxic metal. Therefore, at the Yelang reservoir in Guizhou province, eco-toxicological tests were carried out using Daphnia pulex. The Geo-Accumulation Index and Potential Ecological Risk Index were used to assess the environmental risk of $\mathrm{Cd}$ in sediments. The $\mathrm{Cd}$ contents in the sediments of Yelang reservoir ranged from 2.51 to $5.23 \mathrm{mg} \mathrm{kg}^{-1}$, while the $\mathrm{LC}_{50}$ values of the acute toxicity test of Daphnia pulex and Cd at 24, 48, 72, and $96 \mathrm{~h}$ were 1.17, 0.50, 0.24, and $0.12 \mathrm{mg} \mathrm{L}^{-1}$, respectively, giving a Safe Concentration threshold of Cd of $1.20 \times 10^{-3} \mathrm{mg} \mathrm{L}^{-1}$ in the water body. Based on curve fitting the solid-liquid two-phase distribution model of cadmium in Yelang reservoir was $\mathrm{Y}=7.59 \times 10^{-9} \times \mathrm{X}^{2.58}\left(\mathrm{R}^{2}=0.9995\right)$. The safety threshold sediment $\mathrm{Cd}$ concentration was $103 \mathrm{mg} \mathrm{kg}^{-1}$, and was much higher than the Cd content in the sediment of the Yelang reservoir. The Geo-Accumulation Index ( $\left.I_{g e o} 2.432-3.491\right)$ results show that the sediments had reached medium-strong or strong risk levels. The Potential Ecological Risk Index ( $\left.E_{r}^{i} 242.8-505.9\right)$ reached a very high or extremely high-risk level. However, due to high concentrations of $\mathrm{Ca}^{2+}$ and $\mathrm{Mg}^{2+}$, and the $\mathrm{pH}$ being in the neutral-alkaline range of water body in karst areas, the Daphnia ecotoxicology evaluation method showed slight ecological risk, quite different from other assessment results, thus this method could be considered to use in such areas.
\end{abstract}

Keywords: cadmium; sediment; Daphnia pulex; ecotoxicology; $\mathrm{LC}_{50}$; ecological risk assessment; karst areas

\section{Introduction}

Sediment is an important accumulation site for many natural and anthropogenic heavy metals (HMs) [1,2]. The HMs' concentration within the sediment is perhaps higher in degree than the overlying water [3]. Sediments create very demanding environments for aquatic organisms, as a results harboring pollutants that can directly influence the water quality [2].

A group of freshwater zooplankton commonly referred to as Cladocera's are broadly spread in the aquatic environment, which are available in an extensive range of habitats and are significant links in various food chains [4]. For instance, Daphnia sp. are widely utilized to explore the acute and chronic toxicity of industrial and agricultural chemicals in aquatic ecosystems [5]. This is evident by their relatively short life cycle, less space requirement, adaptability to laboratory conditions, and sensitivity to a wide range of aquatic contaminants [6] and trace quantities of toxic heavy metals in aquatic systems. The trace elements of Cadmium are present in the aquatic environment, which usually leads to significant negative consequences if concentrations are sufficiently raised [7]. Consequently, 
affecting the growth rate of the population of Cladocerans [8]. Moreover, acute experiments have shown that cadmium is more toxic to daphniids in high temperature compared to low temperature [9]. Interestingly, toxicity may decline if a greater amount of energy can be directed to endure the toxic stress within higher food levels [10].

Numerous indexes have been put forward to assess the environmental risk of HMs in lake sediments based on the total content, bioavailability, and toxicity. These indexes include the enrichment factor, geo-accumulation index, pollution index, potential ecological risk index (RI), and so on [11-13]. However, the different evaluation indexes have varying limitations [1,14]. For instance, the Geo-Accumulation Index (Igeo) method of Müller is the current classical method of assessing the ecological risk of metals in sediments [15]. The Potential Ecological Risk Index (RI) method proposed by Hakanson [16], which is based on the research theory of sedimentology, has also been widely used by researchers both nationally and internationally to assess ecological risks of metals in sediments and soils [11-13]. Both methods are based on the assessment of the entire amount of metals without considering the biological effects of metals in sediments or the interaction between water ions.

Besides the mentioned indexes above, other approaches have been suggested, such as the development of theoretical and empirical single guidelines, evaluations of populations and communities, interstitial water quality, tissue residue, and spiked sediment toxicity, including laboratory and field toxicity testing of single species [1,3]. For instance, the calculation of toxic units is one way to estimate both the concentration and potential toxicity of multiple chemicals in sediments. The concentrations of toxicant in pore-water are divided by the $\mathrm{LC}_{50}$ for a reference organism $[1,3,17]$. These laboratory toxicity tests are of great importance, because they provide information for determining and managing decisions and the consequences of these decisions. Moreover, these tests are critical to the establishment of effective prediction of genuine benthic effect in the environment and the development of appropriate guidance for their application within a regulatory framework $[1,3,17,18]$. However, very few studies have attempted to compare and combine indexes, including the geo-accumulation index, and potential ecological risk with the $\mathrm{LC}_{50}$ Daphnia Pulex toxicity test to assess the environmental risk of HMs and detect the specific effects of chemicals on living organisms in lake sediments. These methods will provide adequate information to analyze and understand the ecotoxicology and biotoxic effects of HMs on zooplankton. Thus, an inclusive risk assessment should be given consideration based on a comparison among these indexes.

Guizhou province, located in the southwest of China, is an abnormal geochemical region with respect to cadmium $(\mathrm{Cd})$, representing high background levels of metals $[19,20]$. For instance, Ling [21] has shown statistically that the geochemical background value of $\mathrm{Cd}$ in soils and sediments in Guizhou Province is $0.31 \mathrm{mg} \mathrm{kg}^{-1}$. This is higher than in nonkarst regions and is 2.46 times higher than the average value of water sediments in China $0.126 \mathrm{mg} \mathrm{kg}-1$ [22]. Several studies have found that $\mathrm{Cd}$ is the leading metal pollutant in various karst lakes, with very high ecological risks [20,22]. The primary objective of this study is to assess the ecological risk of $\mathrm{Cd}$ in sediments of Yelang reservoir located in the Guizhou Province based on the D. pulex acute toxicity test. A comparative analysis of GeoAccumulation Index (Igeo) and Potential Ecological Risk Index methods were conducted to provide additional references for environmental and ecological risk assessment.

\section{Materials and Methods}

\subsection{Study Area}

Yelang reservoir is located $35 \mathrm{~km}$ North of Anshun City, Guizhou Province, in the middle of Sancha Lake, north of Puding County. The reservoir area is about 20 square kilometers, and the water storage is about 420 million cubic meters. Its upstream tributaries into the lake are mainly Sancha Lake and Boyu Lake. The main structures at Yelang reservoir are the middle and upstream comprising Permian and Triassic carbonates, whilst the downstream is generally Cambrian, Ordovician and Silurian carbonate. Moreover, it 
displays a highly developed karst topography that accounted for 71.5 of the area, rich in mineral resources, mainly coal, iron, ore, copper, and aluminum-zinc. The principal landform is agricultural land, which is practically used for sewage irrigation owing to karst rock desertification [20]. The reservoir has been used for power generation, flood control, tourism, and water supply. Its basic parameters are shown in Table 1.

Table 1. Basic parameters at Yelang reservoir.

\begin{tabular}{ccccccc}
\hline $\begin{array}{c}\text { Total } \\
\text { Reservoir } \\
\text { Capacity } / \mathbf{k m}^{3}\end{array}$ & $\begin{array}{c}\text { Normal } \\
\text { Reservoir } \\
\text { Capacity } / \mathbf{k m}^{3}\end{array}$ & $\begin{array}{c}\text { Normal } \\
\text { Catchment } \\
\text { Area/ } / \mathbf{k m}^{2}\end{array}$ & Flow $/ \mathbf{k m}^{3}$ & Distance/km & Age/a & $\begin{array}{c}\text { Evolution } \\
\text { Stage }\end{array}$ \\
\hline 4.2 & 2.48 & 19.25 & 33.8 & 238.4 & 24 & Middle level \\
\hline
\end{tabular}

The above data are from [23].

\subsection{Sample Collection}

Sediment sampling was done from 15 randomly selected sampling points at the Yelang reservoir in June 2016 (Figure 1). Sediment samples were collected at depths of $0-8 \mathrm{~cm}$ from the sites. The collection site was divided into three areas, namely the upstream Sancha lake area, midstream Dachuanbian and Shachong area and downstream Tianfen and Shawan area of the reservoir. The samples were placed in bags, sealed, and taken to the laboratory within $24 \mathrm{~h}$ after sampling. Prior to the collection of the sediment samples, surface water samples were collected at the 15 sites for water characterization, major ions, and metal analysis.

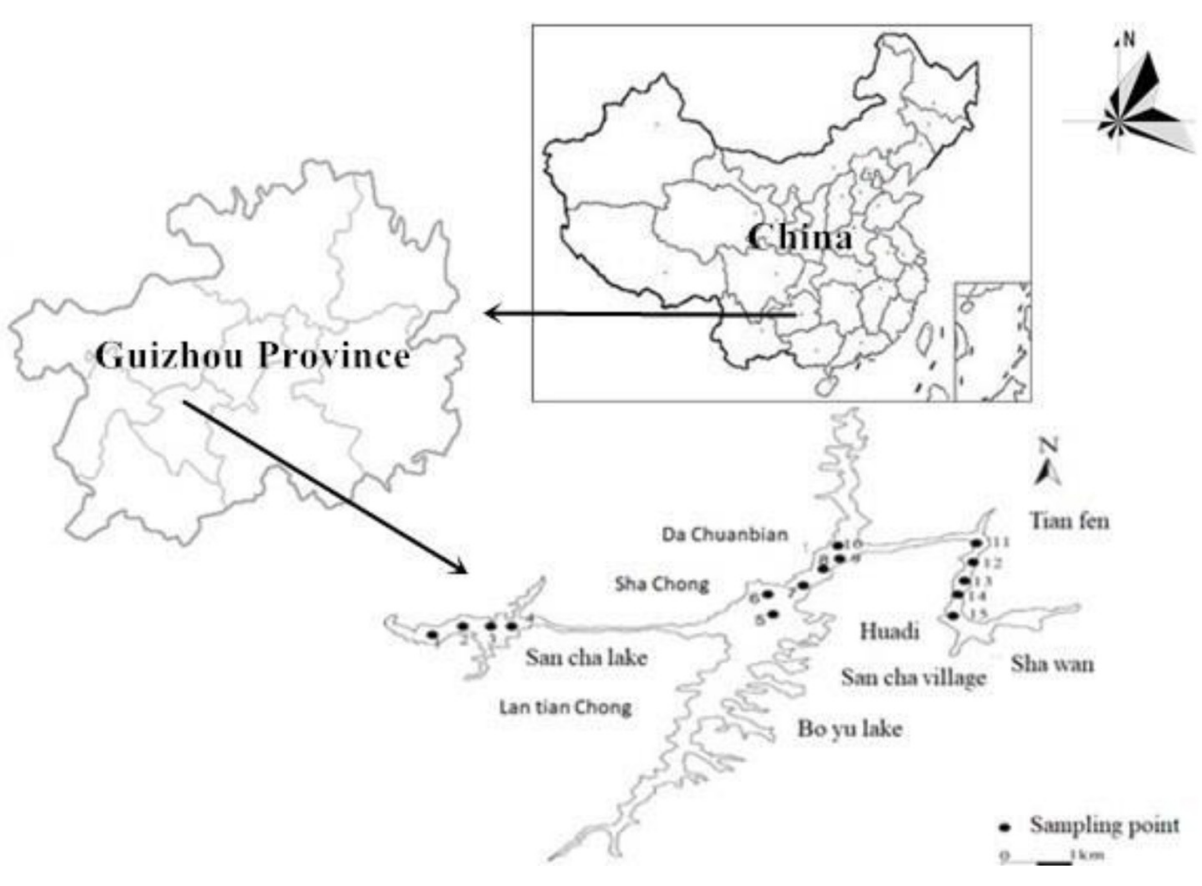

Figure 1. Distribution of sampling sites at Yelang reservoir in Guizhou province.

\subsection{Sample Determination}

The samples were air-dried to remove impurities followed by grinding and later put in a 100-mesh nylon sieve for subsequent analysis. Total cadmium in the sediment was extracted by the $\mathrm{HNO}_{3}-\mathrm{HF}-\mathrm{HClO}_{4}$ triacid digestion method and determined by inductively coupled plasma mass spectrometer (X2 ICP-MS, Thermo Fisher Scientific, Waltham, MA). A parallel sample was set up in the experiment to ensure the accuracy of the measured data. The standard reference material GBW07405 (GSS5) was used for quality control. 
For each water sample, the water temperature (t), conductivity (EC), $\mathrm{pH}$, and other parameters for the overlying water were measured using a portable multiparametric water quality analyzer (DZB-718, Shanghai Leici Instrument Inc., Shanghai, China). The water samples for calcium and magnesium ions analysis were acidified with high purity nitric acid $\left(\mathrm{HNO}_{3}\right)$ to a $\mathrm{pH}<2$. Moreover, the results were determined by ICP-AES (ACTIVA-M, Horiba, Kyoto, Japan). The final results are shown in Table 2.

Table 2. Water quality parameters and main ionic composition at Yelang reservoir.

\begin{tabular}{ccccccc}
\hline $\mathrm{pH}$ & $\mathrm{EC} / \mu \mathrm{s} \mathrm{cm}^{-1}$ & $\mathrm{~T} /{ }^{\circ} \mathrm{C}$ & $\mathrm{DO} / \mathrm{mg} \mathrm{L}^{-1}$ & $\mathrm{Ca}^{2+} / \mathrm{mg} \mathrm{L}^{-1}$ & $\mathbf{M g}^{2+} / \mathrm{mg} \mathrm{L}^{-1}$ & $\mathbf{H C O}_{3}{ }^{-} / \mathrm{mg} \mathrm{L}^{-1}$ \\
\hline 7.92 & 535 & 24.6 & 8.35 & 56.44 & 15.15 & 151.87 \\
\hline
\end{tabular}

The definitions for the abbreviations within the table are as follows; $\mathrm{pH}$, Water Temperature ( $\mathrm{t}$ ), Electrical Conductivity (EC), Dissolved Oxygen (DO), Calcium Ions $\left(\mathrm{Ca}^{2+}\right.$, Magnesium Ion $\left(\mathrm{Mg}^{2+}\right)$, and Bicarbonate Ion $\left(\mathrm{HCO}_{3}{ }^{-}\right)$.

\subsection{Biotoxicity Experimental Design}

\subsubsection{Test Organism and Culture Conditions}

Organism experiment and culture conditions followed the procedures of $\mathrm{Wu}[24] . \mathrm{D}$ pulex were obtained from the Chinese Environmental Science Academy and monocultured in the laboratory of Guizhou University. The culture was maintained at $20.0 \pm 0.5{ }^{\circ} \mathrm{C}$ with a photoperiod of $14 \mathrm{~h}$ light: $10 \mathrm{~h}$ dark, and light intensity was around $1200 \mathrm{lux}$. The fresh Scenedesmus obliquus $\left(2.0 \times 10^{5}\right.$ cells $\left./ \mathrm{mL}\right)$ was used as a daily feed. Throughout the experiment, half the water in the culture containers was replaced three times weekly. $D$. pulex neonates at $48 \mathrm{~h}$ of age were collected for subsequent test.

\subsubsection{Test Material and Water Dilution}

The culture medium was prepared following [25] with slight modifications. Basically, tap water was oxygenated with an oxygen action machine for more than three days until it reached $\mathrm{DO}>8 \mathrm{mg} \mathrm{L}^{-1}$. The $\mathrm{Cd}^{2+}$ toxin was prepared by dissolving $\mathrm{CdCl}_{2} 2 \mathrm{H}_{2} \mathrm{O}$ in deionized water, and the final concentration was $100 \mathrm{mg} \mathrm{L}^{-1}$, and kept at $4{ }^{\circ} \mathrm{C}$. The simulated lake water was prepared following the prescribed diluent water formula for Daphnia-China National Standard Formula GB/T13266-1991 [26]: A total of $1 \mathrm{~mol} \mathrm{~L}^{-1}$ high purity hydrochloric acid and $1 \mathrm{~mol} \mathrm{~L}^{-1}$ high purity sodium hydroxide were used and regulated in $7.8 \pm 0.2$ of $\mathrm{pH}$.

\subsubsection{Simulation of Sediment Samples with Different Concentration Gradients}

The labeling method of sediment samples of different pollution gradients was simulated based on [27] with slight modification. Eight beakers of capacity 1 L, each numbered 1 to 8 , were used to fill the simulated sediment samples. Two hundred grams of dried and sieved sediment was put into each beaker and filled with $800 \mathrm{~mL}$ of simulated lake water at room temperature. All beakers' contents were mixed well with a stir bar and then kept for 3 days. After, the overlying water was poured. The 8 beakers were spiked with varying quantities of $\mathrm{CdCl}_{2}$ 0, 50,100, 200, 600, 800, 1000, and $2000 \mu \mathrm{g} \mathrm{mL}^{-1}$, respectively. The samples were thoroughly mixed and kept for 7 days. Next, sediments were "washed" with clean simulated lake water every 5 days. The total $\mathrm{Cd}$ was measured before each washing. The washing involved draining most of the overlying water, refilling and stirring. The water renewal was repeated until it stabilizes and the process was completed after 40 days. At this point, it was observed that $\mathrm{Cd}$ had reached an equilibrium state between the column water and the sediment. Sediment samples were then dried naturally for analysis.

The overlying water samples were filtered through a $0.45 \mu \mathrm{m}$ filtration membrane before the analysis. Simultaneously, the sediment samples were digested with a mixture of high purity $\mathrm{HNO}_{3}, \mathrm{HF}$, and $\mathrm{HClO}_{4}$ in digested vessels. Lastly, $\mathrm{Cd}$ concentrations were 
analyzed by inductively coupled plasma mass spectrometry (ICP-MS, ACTIVA-M, Horiba, Kyoto, Japan). The conditional distribution coefficient was calculated as follows:

$$
\mathrm{Kp}=\mathrm{Cs} / \mathrm{Cw}
$$

where $\mathrm{Cs}$ is the $\mathrm{Cd}$ content in the sediment $\left(\mu \mathrm{g} \mathrm{g}^{-1}\right)$, and $\mathrm{Cw}$ is the $\mathrm{Cd}$ concentration in the overlying water $\left(\mu \mathrm{g} \mathrm{mL}^{-1}\right)$.

\subsubsection{Acute Toxicity Test of Cd to Daphnia pulex in Water Bodies}

Acute toxicity tests were conducted with Daphnia pulex. The test solution preparation followed standard guidelines ISO [28]. All steps and details concerned with these tests are reported [25]. Preliminary test was performed to determine the range of the maximum concentration that inhibited the movement of $100 \%$ of the D. pulex. Based on the set in equal logarithmic spacing, the toxic concentration intervals were determined, setting the $\mathrm{Cd}^{2+}$ concentration gradient to $0,0.1,0.18,0.32,0.56,1.01,1.82$, and $3.27 \mathrm{mg} \mathrm{L}^{-1}$. The determination of $\mathrm{LC}_{50}$ was based on ISO [28], and Zhou and Zhang [29]. D. pulex was first rinsed in the simulated lake water 3 times, 5 min each time. Ten neonates were transferred to new test solutions with different concentrations of toxin solution $(100 \mathrm{~mL})$. The conditions were the same as the culture conditions except for no feeding during the test. The test was conducted at a constant temperature of $20.0 \pm 0.5^{\circ} \mathrm{C}$. The mortality were defined based on sinking to the bottom of the water or does not display movement in the container.

The Safe Concentration (SC) of cadmium was calculated based on the equation given below:

$$
\mathrm{SC}=96 \mathrm{~h}-\mathrm{LC}_{50} \times \mathrm{AF}
$$

AF is the application factor, which takes a value of 0.1 or 0.01 [30]. According to the acute toxicity of the different chemical substances, cadmium is a toxic substance with a low decomposition and high accumulation rate, hence the value 0.01 [31,32].

\subsubsection{Acute Toxicity Test of Cd to Daphnia pulex in Sediments}

Before the exposure experiment, two duplications of the simulated sediment, each weighing $45 \mathrm{~g}$. were mixed with $180 \mathrm{~mL}$ of the simulated clean lake water. After being placed for 7 days, 40 Daphniids were put in one of the duplications exposing D. pulex to the water-sediment system. The other duplication filled with overlying water was drained and 40 Daphniids were added for the overlying water system experiment. D. pulex were extracted after $72 \mathrm{~h}$ of exposure, and the mortality rate was recorded, according to [27] with slight modification.

\subsubsection{Measurement of the Accumulation of Daphnia pulex Body}

After exposure, $10-15 D$. pulex from each concentration group were taken and placed into simulated clean lake water for $1-2 \mathrm{~h}$ to let the $D$. pulex remove the metal from the internal organs. The D. pulex were subsequently removed and washed with distilled water twice. The samples were dried at $80^{\circ} \mathrm{C}$ and then digested with concentrated $\mathrm{HNO}_{3}$ (Superior purity, $68 \%$ ) at $110{ }^{\circ} \mathrm{C}$ till the solution was transparent. After cooling, $2 \% \mathrm{HNO}_{3}$ (high purity) was used to dilute the volume to a measurable range. The $\mathrm{Cd}$ concentrations in digested organisms were analyzed by inductively coupled plasma-mass spectrometry (ICP-MS).

\subsection{Risk Assessment Method for Heavy Metals in Sediments \\ 2.5.1. Geo-Accumulation Index Method}

The Geo-Accumulation Index $\left(I_{g e o}\right)$ is one of the most widely used methods for the quantitative evaluation of metals in sediments. It reveals the changing characteristics of the distribution of metals and identifies the environmental impact of human activities. It 
has been used by researchers to evaluate the risk of metals in sediments from rivers [13] and lakes and reservoirs [12]. The calculation formula was based on [13,15] as follows:

$$
I_{\text {geo }}=\log _{2} \frac{C_{i}}{k \times B_{i}}
$$

where $C_{i}$ is the measured concentration of the element in the sample, $k$ is the background value change that may be caused by the action of natural rock formation, the overall value is 1.5 , and $B_{i}$ is the geochemical background value of the element in the soil. The classification standards of Müller [15] are shown in Table 3.

Table 3. Geo-Accumulation Index ( $\left.I_{g e o}\right)$ and classification of pollution level.

\begin{tabular}{ccc}
\hline Geoaccumulation Index $\left(\boldsymbol{I}_{\text {geo }}\right)$ & Rank & Pollution Level \\
\hline$I_{\text {geo }} \leq 0$ & 0 & Unpolluted \\
$0<I_{\text {geo }} \leq 1$ & 1 & Unpolluted to moderately polluted \\
$1<I_{\text {geo }} \leq 2$ & 2 & Moderately polluted \\
$2<I_{g e o} \leq 3$ & 3 & Moderately to strongly polluted \\
$3<I_{\text {geo }} \leq 4$ & 4 & Strongly polluted \\
$4<I_{\text {geo }} \leq 5$ & 5 & Strongly to extremely polluted \\
$5<I_{g e o} \leq 10$ & 6 & Extremely polluted \\
\hline
\end{tabular}

\subsubsection{Potential Ecological Risk Index Method}

The method is relatively fast, convenient, and straightforward. It not only reveals the impact of various pollutants in sediment environments of a particular area, but it also reveals the combined comprehensive effects of multiple contaminants in the environment. A single metal's Potential Ecological Risk Index were determined by following the formula below [16] and developed by Qi et al. [33]:

$$
\begin{gathered}
E_{r}^{i}=T_{r}^{i} \times C_{f}^{i}, \\
C_{f}^{i}=\frac{C^{i}}{C_{n}^{i}}
\end{gathered}
$$

where $E_{r}^{i}$ the is potential ecological risk factors for each heavy metal; $T_{r}^{i}$ The toxicity response factor for the given element of " $i$ ", the toxicity response factor of $\mathrm{Cd}$ is 30 and $C_{f}^{i}$ the pollution coefficient of a single element of " $i$ "; $C^{i}$ is the measured concentration of heavy metal in sediment; $C_{n}^{i}$ which is the background value of heavy metal in sediment. The superscript " $i$ " indicates the specific pollutant. The classification standards are shown in Table 4.

Table 4. Criteria for individual potential ecological risk coefficient indices $\left(E_{r}^{i}\right)$.

\begin{tabular}{ccc}
\hline Rank & $\begin{array}{c}\text { Individual Potential Ecological Risk } \\
\text { Index }\left(\boldsymbol{E}_{r}^{\boldsymbol{i}}\right)\end{array}$ & $\begin{array}{c}\text { Individual Potential Ecological Risk } \\
\text { Level }\end{array}$ \\
\hline 1 & $<40$ & Slight \\
2 & $40-80$ & Medium \\
3 & $80-160$ & High \\
4 & $160-320$ & Very High \\
5 & $\geq 320$ & Extremely High \\
\hline
\end{tabular}

\subsection{Data and Statistical Analysis}

The Data Processing System (DPS 2000) was used to carry out statistical analysis of experimental data. The probability value method was applied to obtain the corresponding four times under the $\mathrm{LC}_{50}$ [34]. The toxicological concentration and toxic regression equation for Daphnia mortality rate in overlying water was established, and chi-square was tested on regression equations formula [35] using Origin 2019b. Each value signifies 
the mean of four replicates \pm standard deviation (SD). Levels of statistical significance are shown as ${ }^{*} p<0.05$ and ${ }^{* *} p<0.01$.

\section{Results and Discussion}

\subsection{Distribution Coefficient and Fitted Model of Cd in Simulated Sediment and Overlying Water Systems}

This crucial stage was carried out by mixing concentrated $\mathrm{Cd}$ and sediments. The $\mathrm{Cd}$ contamination of the simulated sediment samples were obtained after simulated lake water treatment with varying contents of $\mathrm{Cd}^{2+}$. After repeated washing, $\mathrm{Cd}$ reached an equilibrium state between column water and sediment. The concentration of $\mathrm{Cd}$ in the simulated sediment and the overlying water system are shown in Figure 2. When the concentration of exogenous $\mathrm{Cd}$ increases, the $\mathrm{Cd}$ concentration in sediments and overlying water also increase. The ranges of $\mathrm{Cd}$ concentration in the sediment was between 2.7 and $3530.0 \mathrm{mg} \mathrm{kg}^{-1}$, while the Cd concentration in the overlying water system was 0.00 $10.40 \mathrm{mg} \mathrm{kg}^{-1}$. The distribution coefficients were between 339.42 and $28,787 \mathrm{~L} \mathrm{~kg}^{-1}$.

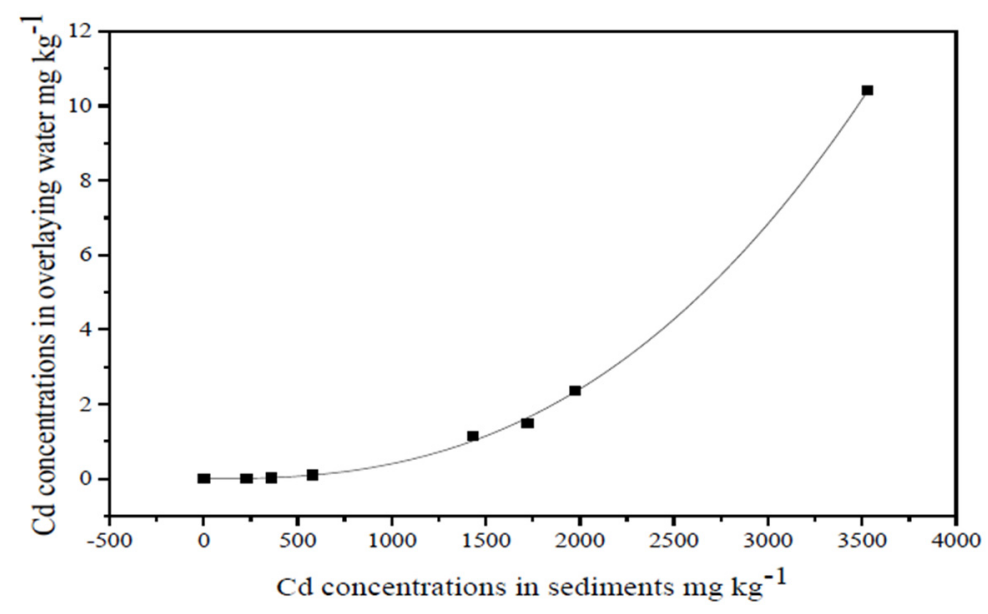

Figure 2. Cadmium concentrations in simulated sediments and overlying water systems (curve fitted by the power function).

The distribution coefficient showed a tendency to decrease because the adsorption sites on the sediment gradually became saturated. When the $\mathrm{Cd}$ concentration of the marker increases, the adsorption capacity of the sediment decreases. The $\mathrm{Cd}$ concentration relationship between the two systems was fitted by the model $\mathrm{Y}=7.59 \times 10^{-9} \times \mathrm{X}^{2.58}$ $\left(R^{2}=0.9995\right)$. Additionally, based on curve fitting, the solid-liquid two-phase distribution model of cadmium in the Yelang reservoir was $Y=7.59 \times 10^{-9} \times X^{2.58}\left(R^{2}=0.9995\right)$. The safety threshold of total cadmium concentration in the sediment was $103 \mathrm{mg} \mathrm{kg}^{-1}$, which was used as a reference value to evaluate the ecological risk of the sediment. The cadmium content in the sediments of Yelang reservoir was at a low level, and the environmental and ecological risks equally low. This was similar to the prior study conducted by Luo et al. [20], in which their finds claimed that the deposition rate of heavy metals in the Yelang Lake sediment is higher than the release rate, and the ecological risk from heavy metals is relatively low. When the release of heavy metals in sediments occurs, it can speedily affect the overlying water in a short time and, consequently, affect the water quality significantly [36].

\subsection{Ecological Risk Assessment Based on Daphnia pulex Bio Toxicity Test}

In this study, Daphnia pulex was selected as test organisms. The choice of D. pulex is owed to its sensitivity to toxins and the ability of obtaining precise information. In addition, it is recommended as a standard "Test for Acute Inhibition of Chemical Tritium GB/T 21830-2008)" [37] in carrying out such investigations. 


\subsubsection{Lethal Effect of $\mathrm{Cd}^{2+}$ on Daphnia pulex}

The sublethal concentration $\mathrm{LC}_{50}$ and lethal effect of $\mathrm{Cd}^{2+}$ in D. pulex at different times are shown in Table 5. Based on the lethal effect of $\mathrm{Cd}^{2+}$ on D. pulex, the sublethal concentration values and toxicological regression equations were obtained at 24, 48, 72, and $96 \mathrm{~h}$. The results show that, along with time, the sublethal concentration indicated a tendency to decrease gradually. In addition, the chi-square value of the toxicological equation fitted in each period was less than the critical value $\left(x^{2}=9.49\right)$. This illustrates that the toxicological regression equation describing the bio-toxicity of $\mathrm{Cd}^{2+}$ on D. pulex was feasible. The correlation coefficients for different times were $>0.90$. According to the Safe Concentration formula, $\mathrm{SC}=96 \mathrm{~h}-\mathrm{LC}_{50} \times \mathrm{AF}$, where $\mathrm{AF}$ took the value of 0.01 and gives the Safety Concentration SC $=1.20 \times 10^{-3} \mathrm{mg} \mathrm{L}^{-1}$. This value is similar to previously reported values [32], with the sample possessing a limit of second-class water standard of $5 \times 10^{-3} \mathrm{mg} \mathrm{L}^{-1}$. These results are generally less than the recommended ranges of the surface water environmental quality standard GB3838 — 2002 [38].

Table 5. The lethal effects of $\mathrm{Cd} 2+$ on D. pulex.

\begin{tabular}{cccccc}
\hline $\begin{array}{c}\text { Exposure } \\
\text { time/h }\end{array}$ & $\mathbf{L C}_{\mathbf{5 0}} / \mathbf{m g ~ L}^{-\mathbf{1}}$ & $\begin{array}{c}\mathbf{9 5 \%} \\
\text { Confidence } \\
\text { İnterval }\end{array}$ & $\begin{array}{c}\text { Toxicology } \\
\text { Regression } \\
\text { Equation }\end{array}$ & $\begin{array}{c}\text { Coefficient of } \\
\text { Correlation } \mathbf{R}^{2}\end{array}$ & $\begin{array}{c}\text { Chi-Square } \\
24\end{array}$ \\
\hline 48 & 1.17 & $0.85 \sim 1.60$ & $\mathrm{y}=4.89+1.66 \mathrm{x}$ & 0.98 & 0.01 \\
72 & 0.50 & $0.23 \sim 1.03$ & $\mathrm{y}=6.38+4.47 \mathrm{x}$ & 0.92 & 0.68 \\
96 & 0.24 & $0.15 \sim 0.38$ & $\mathrm{y}=7.16+3.46 \mathrm{x}$ & 0.97 & 0.23 \\
\hline
\end{tabular}

The fundamental concept in toxicology is the concentration-response relationship. For instance, toxicological evaluation naturally uses estimation points such as $\mathrm{LC}_{50}$ to compare species sensitivities $[17,39]$. Therefore, in this study, the $96 \mathrm{~h} \mathrm{LC}_{50}$ values of several other aquatic organisms were collected from previous reports and summarized in Table 6. (Due to different experimental designs in the literature, if a species has multiple data, then only the lowest values were collected).

Table 6. The $96 \mathrm{~h}-\mathrm{LC}_{50}$ values of some common aquatic organisms in other studies.

\begin{tabular}{|c|c|c|c|}
\hline Species & $96 \mathrm{~h}-\mathrm{LC}_{50} / \mathrm{mg} \mathrm{L}^{-1}$ & Author(s) & $\begin{array}{l}\text { Safe Concentration } \\
\qquad / \mathrm{mg} \mathrm{L}^{-1}\end{array}$ \\
\hline Sipunculus nudus & 24.328 & {$[40]$} & 0.24 \\
\hline Misgurnus anguillicaudatus & 1753.8 & [41] & 17.54 \\
\hline Argopecten irradiams & 3.45 & [31] & 0.03 \\
\hline Mytilus coruscus & 3.1 & {$[42]$} & 0.03 \\
\hline Eriocheir sinensis & 40.279 & [43] & 0.40 \\
\hline Megalobrama terminalis & 3.2 & [44] & 0.03 \\
\hline Carassius auratus gibelio & 26.51 & [45] & 0.27 \\
\hline Gambusia affinis & 22.55 & [46] & 0.23 \\
\hline Tanichthys albonubes & 4.447 & [47] & 0.04 \\
\hline Ctenopharyngodon idella & 23.51 & [48] & 0.24 \\
\hline Tigriopus japonicus & 6.31 & [32] & 0.06 \\
\hline Chironomus javanus & 0.06 & [49] & $6 \times 10^{-4}$ \\
\hline Cyathura carinata & 37 & [50] & 0.37 \\
\hline Rasbora sumatrana & 0.1 & & 0.001 \\
\hline Poecilia reticulata & 1.06 & [17] & 0.0106 \\
\hline Kryptolebias marmoratus & $6.43 \times 10^{-3}$ & [51] & $6.43 \times 10^{-5}$ \\
\hline Fundulus heteroclitus & $2.94 \times 10^{-3}$ & [51] & $2.94 \times 10^{-5}$ \\
\hline
\end{tabular}


Table 6. Cont.

\begin{tabular}{|c|c|c|c|}
\hline Species & $96 \mathrm{~h}-\mathrm{LC}_{50} / \mathrm{mg} \mathrm{L}^{-1}$ & Author(s) & $\begin{array}{l}\text { Safe Concentration } \\
\qquad / \mathrm{mg} \mathrm{L}^{-1}\end{array}$ \\
\hline Macrobrachium lanchesteri & 0.007 & \multirow{8}{*}[52]{} & $7 \times 10^{-5}$ \\
\hline Stenocypris major & 0.013 & & $1.3 \times 10^{-4}$ \\
\hline Nais elinguis & 0.027 & & $2.7 \times 10^{-4}$ \\
\hline Chironomus javanus & 0.06 & & $6 \times 10^{-4}$ \\
\hline Rasbora sumatrana & 0.1 & & $1 \times 10^{-3}$ \\
\hline Poecilia reticulata & 0.17 & & $1.7 \times 10^{-3}$ \\
\hline Duttaphrynus melanostictus & 0.32 & & $3.2 \times 10^{-3}$ \\
\hline Melanoides tuberculata & 1.49 & & $1.49 \times 10^{-2}$ \\
\hline Eurytemora affinis & $\begin{array}{c}\text { Male } 127.8 \\
\text { Female } 90.0\end{array}$ & [39] & $\begin{array}{l}1.28 \\
0.09\end{array}$ \\
\hline Orconectes juvenilis & 0.06 & \multirow{6}{*}{ [53] } & $6 \times 10^{-4}$ \\
\hline Orconectes placidus & 0.037 & & $3.7 \times 10^{-4}$ \\
\hline Orconectes virilis & 3.3 & & 0.03 \\
\hline Procambarus acutus & 0.368 & & $3.68 \times 10^{-3}$ \\
\hline Procambarus alleni & 3.07 & & 0.03 \\
\hline Procambarus clarkii & 0.624 & & $6.24 \times 10^{-3}$ \\
\hline
\end{tabular}

The $96 \mathrm{~h} \mathrm{LC}_{50}$ value is found to be $6.43 \times 10^{-3}-1753.8 \mathrm{mg} \mathrm{L}^{-1}$, and its Safe Concentration was evaluated based on the formula SC $=96 \mathrm{~h}-\mathrm{LC}_{50} \times \mathrm{AF}$ (value of 0.01), calculated as $6.43 \times 10^{-5}-17.54$, or $0.05-14,615$ times the D. pulex $96 \mathrm{~h} \mathrm{LC}_{50}\left(0.12 \mathrm{mg} \mathrm{L}^{-1}\right)$ and the Safe Concentration $\left(1.20 \times 10^{-3} \mathrm{mg} \mathrm{L}^{-1}\right)$. In comparison to the collected aquatic organisms mentioned above, the D. pulex is one of the most sensitive aquatic species models in particular for cadmium toxicity [54,55]. Moreover, the $96 \mathrm{~h} \mathrm{LC}_{50}$ of some organisms can only be obtained in harsh environments, as highlighted in the literature [51], with the lowest value of $6.43 \times 10^{-3} \mathrm{mg} \mathrm{L}^{-1}$. Such a low $96 \mathrm{~h} \mathrm{LC}_{50}$ requires the ionic concentration in the water body to be extremely low. After adding a certain amount of calcium and magnesium ions, its value is increased significantly. In this study, it was increased from 0.23 to $23.2 \mathrm{mg} \mathrm{L}^{-1}$, which is higher than the $96 \mathrm{~h} \mathrm{LC}_{50}$ of D. pulex. In addition, compared to the results of other freshwater Daphnia studies, Yang [56] measured the $48 \mathrm{~h}$ sublethal concentration of $\mathrm{Cd}^{2+} 0.62 \mathrm{mg} \mathrm{L}^{-1}$ in Daphnia carinata King (Cladocera-Daphnidae). This is relatively close to this study with a $\mathrm{Cd}^{2+}$ concentration of $48 \mathrm{~h} \mathrm{LC}_{50}=0.50 \mathrm{mg} \mathrm{L}^{-1}$.

Cadmium (Cd) is not an essential element for either plant or animal survival and yet one of the most toxic metals [54,55]. However, similar to a previous report [57], this study also found that the less toxicity for the tested daphniids may very likely be due to the $\mathrm{Cd}$ competing with calcium $\left(\mathrm{Ca}^{2+}\right)$ at enzymatic locations in organisms. The acute toxicity of $C d D$. pulex is significantly minimized by increasing calcium and magnesium concentrations. The findings of this study is also supported by Clifford et al. [7], who explained that the acute toxicity of CdT to D. pulex is significantly influenced by $\mathrm{Ca}$ and $\mathrm{Mg}$, which lower the potential risk of cadmium. Additionally, the less toxicity of the cadmium is evident by the dominance of mobile species in well-aerated water bodies with a $\mathrm{pH}$ closer to $8[58,59]$. Another possible explanation can be given using the results of researches that focused on mRNA expression as an indicator of the response to metals. For instance, Chen et al. [60] reported that miRNAs and metallothionein (MT) play critical roles in D. pulex tolerance to $\mathrm{Cd}$, and confirmed that, when exposed to Cd-polluted environments, aquatic organisms can raise their tolerance to $\mathrm{Cd}$ in order to survive. In Daphnia pulex, different gene expression and high gene duplication rates have been identified, which enhances its adaptation in adverse environmental conditions [55,61].

3.2.2. Mortality Rate and Cd Accumulation of Daphnia pulex after Cd Exposure in Both Systems

Mortality is generally the primary parameter to consider when assessing the impact of contaminants in the environment. Trace metals are predictable by their toxic effects on 
aquatic organisms [39]. This study investigated the toxic effects of Cd on Daphnia pulex in overlaying water and water-sediment systems. It is generally assumed that absorption by organisms will reduce the concentration of metals in water and thus predicted that D. pulex only absorbs $\mathrm{Cd}$ from overlying water. However, because the change in the value of $\mathrm{Cd}$ concentration was small, $\leq 5 \%$, the concentration of $\mathrm{Cd}$ in the overlying water system is negligible. It was assumed that the concentrations of $\mathrm{Cd}$ in the water during the exposure process were constant. The mortality rate of $D$. pulex after exposure to pollutants with different levels of $\mathrm{Cd}$ pollution is shown in Figure 3. The mortality rate of $D$. pulex increases with the increase of $\mathrm{Cd}$ concentration in sediments. When the $\mathrm{Cd}$ concentration in the sediment exceeded $1500 \mathrm{mg} \mathrm{kg}^{-1}$, the mortality rate of D. pulex reached $100 \%$. This suggests that $\mathrm{Cd}$ in the solid phase (sediment) could also intoxicate the Daphnia pulex by sediment mud feeding and other particles. It is supported by Caumette [14], who reported that part of the assessed arsenic signal comes from the sediments ingested by Daphnia pulex when the residues were analyzed with soluble arsenic after extraction. Li et al. [3] argued that $D$. magna or daphniids could absorb some heavy metals, and accumulate more $\mathrm{Cd}$ by assimilating solid particles. Moreover, Barton et al. [1] defended that benthic organisms exposed to metal-contaminated sediments can accumulate metals by ingesting contaminated sediments and other suspended particles, and by exposure to dissolved metals in the overlying water. The overlying water systems and water-sediment systems showed no significant difference ( $t$-test, $p>0.05$ ) in the mortality rate of $D$. pulex. The $\mathrm{Cd}$ content in the D. pulex body after exposure with different levels of $\mathrm{Cd}$ pollution is shown in Figure 4. The Cd content in the D. pulex body increases with the increasing $\mathrm{Cd}$ content in the sediments with significant linear correlation (Overlying water system: $\mathrm{R}^{2}$ $=0.936, p<0.01$; water-sediment systems: $R^{2}=0.973, p<0.01$ ). It is interesting to note that the amount of $\mathrm{Cd}$ in the overlying water increased along with $\mathrm{Cd}$ concentration in sediment. Notably, when the Cd concentrations in sediment were 2.7 and $3530.0 \mathrm{mg} \mathrm{kg}^{-1}$, the concentrations in the overlying water were 0.00 and $10.40 \mathrm{mg} \mathrm{kg}^{-1}$, respectively. This scenario was also observed in a previous study [3]. Their study hence revealed that when the $\mathrm{Cd}$ concentrations in sediment were 344.2 and $742 \mu \mathrm{g} / \mathrm{g}$, the concentrations in the overlying water were 0.531 and $1.76 \mathrm{mg} / \mathrm{L}$, respectively. The findings of this study are supported by the conclusions of previous researches $[3,62]$. The increase in mortality and $\mathrm{Cd}$ accumulation in the two systems was principally owing to the rise in $\mathrm{Cd}$ concentration in the overlying water (see Figure 5).

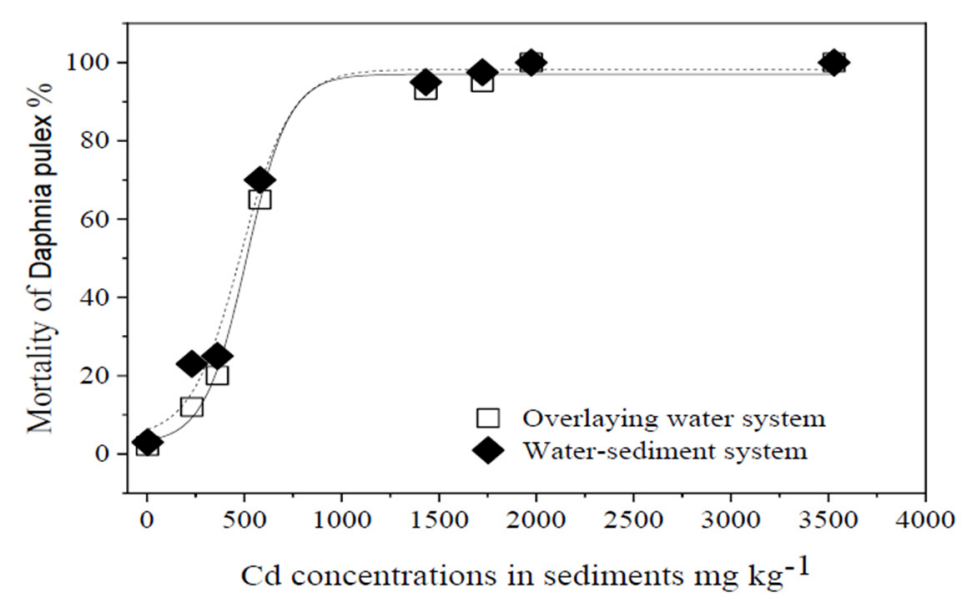

Figure 3. The mortality rate of Daphnia pulex under different Cd pollution levels in sediments (curves fitted by the Boltzmann function). 


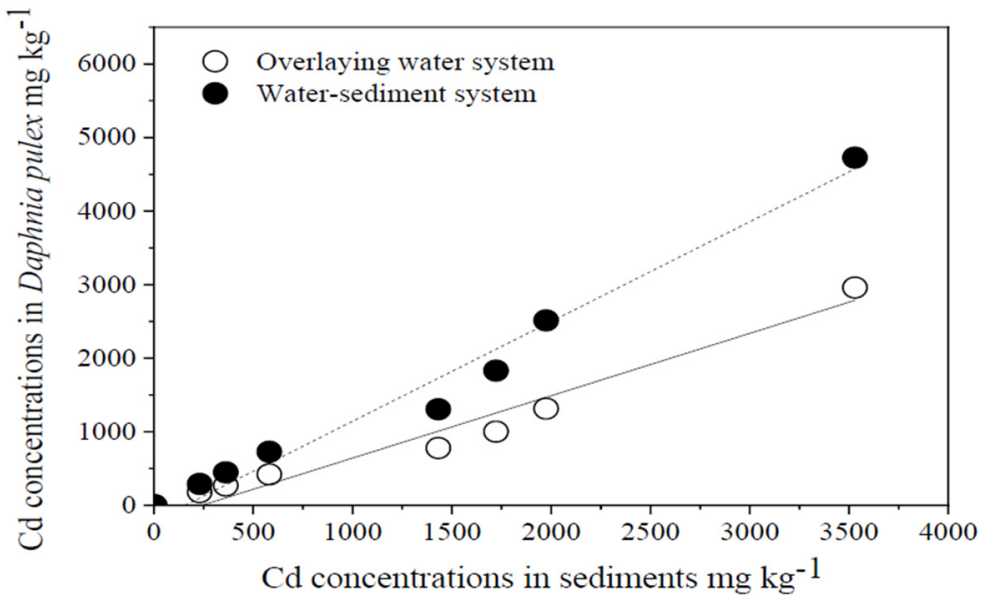

Figure 4. Cadmium concentrations in Daphnia pulex under different Cd pollution levels in sediments.

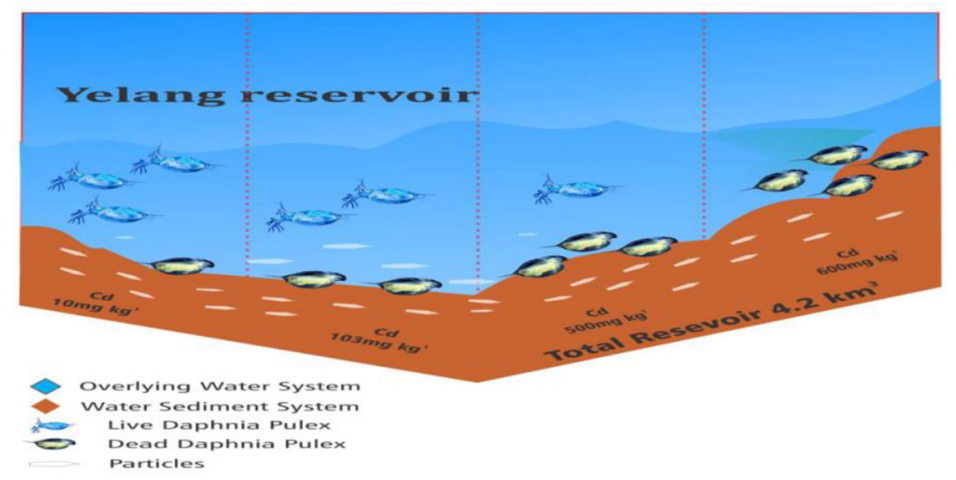

Figure 5. Highlighting the mortality rate of Daphnia pulex under different Cd pollution levels in sediments.

\subsection{Cadmium Content in Sediments of Yelang Reservoir}

The Cd content in the sediments is shown in Table 7. The content ranges from 2.51 to $5.23 \mathrm{mg} \mathrm{kg}^{-1}$ and the average value was $3.95 \mathrm{mg} \mathrm{kg}^{-1}$. The obtained values clearly indicated that the samples exceeded the screening value of soil pollution risk on agricultural land and partly greater than the environmental quality control value of $0.6 \mathrm{mg} \mathrm{kg}^{-1}$ (GB15618-2018, China) [63]. The Cd content in the middle stream and downstream was smaller than the upstream, which could very likely be due to the larger storage area in the middle stream compared to the upstream and downstream. After an absolute reduction, the risk rates of the downstream and midstream were low. The source of cadmium concentration at the Yelang reservoir is mainly from anthropogenic activities, including domestic, agricultural and mining wastes, sewage discharge, and natural factors such as the influence of carbonate rocks of the karst terrain and its high geological background.

\subsection{Ecological Risk Assessment Based on Sedimentology}

The evaluation results of $\mathrm{Cd}$ content in the sediments of the Yelang reservoir by the Geo-Accumulation Index method are shown in Table 7. The index ranges from 2.432 to 3.491 and the contamination levels reached classes III and IV, suggesting medium-strong and strong risk levels. The degree of $\mathrm{Cd}$ pollution in the middle stream is lower than in the upstream and downstream due to the large volume of water which tends to lower potential risk of the Cd contents.

The Potential Ecological Risk Index method evaluation of the $\mathrm{Cd}$ content of the sediments of the Yelang reservoir are shown in Table 7. The risk index ranges from 242.8 to 505.9 with an average value of 381.8 , suggesting that the risks were between 
very strong and extremely strong. The results were identical to the evaluation results of the geo-accumulation index method. There were differences in pollution levels at the upstream, middle, and downstream, such that the hazard index was in the order midstream $<$ downstream $<$ upstream.

Table 7. Concentration and evaluation results of $\mathrm{Cd}$ in sediments at the Yelang reservoir.

\begin{tabular}{|c|c|c|c|c|c|}
\hline $\begin{array}{l}\text { Sampling } \\
\text { Site }\end{array}$ & $\begin{array}{c}\text { Concentration } \\
\text { of } \mathrm{Cd} / \mathrm{mg} \\
\mathrm{kg}^{-1}\end{array}$ & $I_{g e o}$ & $\begin{array}{l}\text { Classification of } \\
\text { Geoaccumulation } \\
\text { Index }\end{array}$ & $E_{r}^{i}$ & $\begin{array}{c}\text { Potential Ecological } \\
\text { Risk Level }\end{array}$ \\
\hline 1 & 4.13 & 3.15 & 4 & 399.3 & Extremely strong \\
\hline 2 & 3.9 & 3.068 & 4 & 377.4 & Extremely strong \\
\hline 3 & 4.19 & 3.17 & 4 & 405.1 & Extremely strong \\
\hline 4 & 4.18 & 3.168 & 4 & 404.5 & Extremely strong \\
\hline 5 & 4.25 & 3.191 & 4 & 410.9 & Extremely strong \\
\hline 6 & 4.45 & 3.259 & 4 & 430.6 & Extremely strong \\
\hline 7 & 3.69 & 2.989 & 3 & 357.2 & Very strong \\
\hline 8 & 4.43 & 3.253 & 4 & 429.1 & Extremely strong \\
\hline 9 & 2.74 & 2.557 & 3 & 264.8 & Very strong \\
\hline 10 & 4.22 & 3.18 & 4 & 407.9 & Extremely strong \\
\hline 11 & 2.51 & 2.432 & 3 & 242.8 & Very strong \\
\hline 12 & 5.23 & 3.491 & 4 & 505.9 & Extremely strong \\
\hline 13 & 2.8 & 2.592 & 3 & 271.3 & Very strong \\
\hline 14 & 5.04 & 3.439 & 4 & 488.1 & Extremely strong \\
\hline 15 & 3.43 & 2.884 & 3 & 332.1 & Extremely strong \\
\hline
\end{tabular}

The results obtained from the Geo-Accumulation Index method and the Potential Ecological Risk Index method showed that the Cd risk of the Yelang reservoir has reached a high-risk level. The Geo-Accumulation Index method pays more attention to the total amount of metals [64]. The Potential Ecological Risk index method combines metal toxicity, the local metal background value, the general migration and transformation law in the sediments, and evaluation of the regional sensitivity to metal pollution $[11,65]$. Both evaluation methods were based on the total amount of metals.

A large quantity of $\mathrm{Ca}, \mathrm{Mg}$, and other alkaline soil metal ions in carbonate rocks in karst areas enter the water body through erosion, weathering, and transportation, thereby increasing the contents of $\mathrm{Ca}^{2+}$ and $\mathrm{Mg}^{2+}$. Furthermore, a significant amount of calcite and dolomite, among others, consume some $\mathrm{H}^{+}$in the aqueous solution during the dissolution process, causing the $\mathrm{pH}$ of the water body to become weakly alkaline, thereby inhibiting the effectiveness of $\mathrm{Cd}[51,57]$. Many studies [32,51] have confirmed that the bio-toxicity of metals will decrease with increasing $\mathrm{pH}$ and hardness of water bodies. Shi [66] and other authors who studied karst areas have found that $\mathrm{Ca}^{2+}$ and $\mathrm{Mg}^{2+}$ contained in water bodies can antagonize the biological toxicity of metals, increasing the $96 \mathrm{~h} \mathrm{LC}_{50}$ of the Daphnia. Xiong [67] confirmed that, along with the increase in the water body's hardness, the sublethal concentration $\left(96 \mathrm{~h} \mathrm{LC}_{50}\right.$ ) and Safe Concentration of Cd on Gobiocypris rarus both increased significantly, showing that the hardness of a water body can effectively reduce the acute toxicity of cadmium in organisms.

\subsection{Analysis of the Application of Ecological Risk Assessment Methods for Cadmium in Karst Lake Reservoir Sediments}

The sediment quality evaluations were mainly focused on specific chemical analysis (Cd) results, and the results obtained are an accurate reflection of its effects on the aquatic animals at the Yelang reservoir. The sediment metal risk assessment system is a largescale system that integrates a variety of uncertainties, such as randomness, greyness, uncertainty, and ambiguity $[11,68,69]$. The application of conventional assessment methods without analysis cannot accurately reveal the real situation of the metal pollution level of sediments [12]. In recent years, some researchers have improved these methods [12,33,70] to make them favorable and adequately applicable. During the assessment of ecological risks in karst areas, the particularity of the region should be taken into account for the evaluation results to be more accurate. However, the biological toxicity test method directly 
revealed the toxic effect of $\mathrm{Cd}$ on D. pulex, and did not require considering the particularity of the regional environment. This study only conducted preliminary toxicity tests and did not consider the effects of biomicroscopy. Further studies are required to assess whether further ranks of consumers in the food chain will produce any ecological risk.

Although karst areas are an abnormal geochemical region with respect to cadmium (Cd), due to the high concentration of $\mathrm{Ca}^{2+}$ and $\mathrm{Mg}^{2+}$ and the $\mathrm{pH}$ remains in the neutralalkaline range of water body, the Daphnia pulex ecotoxicology evaluation method showed slight ecological risk, which is quite different from other methods used for environmental risk assessment, thus the method could be considered to use in such areas.

\section{Conclusions}

The sediment quality evaluations were mainly focused on specific chemical analysis (Cd) results, and the results obtained are an accurate reflection of its effects on the aquatic animals at the Yelang reservoir. The sediment toxicity experiment was carried out by mixing concentrated $\mathrm{Cd}$ and sediments. Based on the bio-toxicity experiment, it was deduced that the Safe Concentration threshold of Cd in the sediment was $103 \mathrm{mg} \mathrm{kg}^{-1}$. The cadmium contents in the sediment of the Yelang reservoir ranged from 2.51 to $5.23 \mathrm{mg}$ $\mathrm{kg}^{-1}$. The Geo-Accumulation Index and the Potential Ecological Risk Index showed that the water environment of the Yelang reservoir had strong to extremely strong ecological risks. However, due to the high concentration of $\mathrm{Ca}^{2+}$ and $\mathrm{Mg}^{2+}$ and that the $\mathrm{pH}$ remains in the neutral-alkaline range, the Daphnia pulex ecotoxicology evaluation method showed slight ecological risk, which is quite different from the current available for environmental risk assessment, thus the method can be considered for use in the karst area. This study only conducted preliminary toxicity tests and did not consider the effects of biomicroscopy, further studies are required to assess whether further ranks of consumers in the food chain will produce any ecological risk.

Author Contributions: Conceptualization, H.L. and Q.L.; data curation, H.L.; formal analysis, F.D., H.L. and M.X.; funding acquisition, H.L.; investigation, F.D.; methodology, H.L., X.W. and M.X.; project administration, H.L.; resources, H.L.; software, Q.L.; supervision, H.L.; writing—original draft, F.D.; writing - review and editing, F.D. All authors have read and agreed to the published version of the manuscript.

Funding: This project was supported by the Joint National Natural Science Foundation of China and Guizhou Province (U1612442); China National Natural Science Foundation (42067028): The Science and Technology Planning Project of Guizhou Province (Qiankehehoubuzu [2020]3001).

Data Availability Statement: The data that support the findings of this study are available from the corresponding author, upon reasonable request.

Acknowledgments: Special thanks to the Joint National Natural Science Foundation of China and Guizhou Province, China National Natural Science Foundation, the Science and Technology Planning Project of Guizhou Province for the funding of this research. The authors would like to thank Hongyan Liu for the guidance and supervision. Finally, special thanks to all the reviewers for their insightful contributions during the review of the article.

Conflicts of Interest: The authors declare that there are no conflicts of interest.

\section{References}

1. Burton, G.A. Metal bioavailability and toxicity in sediments. Crit. Rev. Environ. Sci. Technol. 2010, 40, 852-907. [CrossRef]

2. Hallare, A.V.; Seiler, T.B.; Hollert, H. The versatile, changing, and advancing roles of fish in sediment toxicity assessment-A review. J. Soils Sediments 2011, 11, 141-173. [CrossRef]

3. Li, X.; Peng, W.; Jiang, Y.; Duan, Y.; Ren, J.; Liu, Y.; Fan, W. The Daphnia magna role to predict the cadmium toxicity of sediment: Bioaccumlation and biomarker response. Ecotoxicol. Environ. Saf. 2017, 138, 206-214. [CrossRef] [PubMed]

4. Abe, T.; Saito, H.; Niikura, Y.; Shigeoka, T.; Nakano, Y. Embryonic development assay with Daphnia magna: Application to toxicity of aniline derivatives. Chemosphere 2001, 45, 487-495. [CrossRef]

5. Hanazato, T. Growth analysis of Daphnia early juvenile stages as an alternative method to test the chronic effect of chemicals. Chemosphere 1998, 36, 1903-1909. [CrossRef] 
6. Emmanuel, E.; Keck, G.; Blanchard, J.M.; Vermande, P.; Perrodin, Y. Toxicological effects of disinfections using sodium hypochlorite on aquatic organisms and its contribution to AOX formation in hospital wastewater. Environ. Int. 2004, 30, 891-900. [CrossRef] [PubMed]

7. Clifford, M.; McGeer, J.C. Development of a biotic ligand model to predict the acute toxicity of cadmium to Daphnia pulex. Aquat. Toxicol. 2010, 98, 1-7. [CrossRef]

8. Wong, C.K.; Wong, P.K. Life table evaluation of the effects of cadmium exposure on the freshwater cladoceran, Moina macrocopa. Bull. Environ. Contam. Toxicol. 1990, 44, 135-141. [CrossRef]

9. Heugens, E.H.; Jager, T.; Creyghton, R.; Kraak, M.H.; Hendriks, A.J.; Van Straalen, N.M.; Admiraal, W. Temperature-dependent effects of cadmium on Daphnia magna: Accumulation versus sensitivity. Environ. Sci. Technol. 2003, 37, 2145-2151. [CrossRef]

10. Heugens, E.H.; Tokkie, L.T.; Kraak, M.H.; Hendriks, A.J.; Van Straalen, N.M.; Admiraal, W. Population growth of Daphnia magna under multiple stress conditions: Joint effects of temperature, food, and cadmium. Environ. Toxicol. Chem. Int. J. 2006, 25, 1399-1407. [CrossRef]

11. Zhao, Y.; Xu, M.; Liu, Q.; Wang, Z.; Zhao, L.; Chen, Y. Study of heavy metal pollution, ecological risk and source apportionment in the surface water and sediments of the Jiangsu coastal region, China: A case study of the Sheyang Estuary. Mar. Pollut. Bull. 2018, 137, 601-609. [CrossRef] [PubMed]

12. Yang, J.; Chen, L.; Liu, L.Z.; Shi, W.L.; Meng, X.Z. Comprehensive risk assessment of heavy metals in lake sediment from public parks in Shanghai. Ecotoxicol. Environ. Saf. 2014, 102, 129-135. [CrossRef]

13. Singh, H.; Yadav, S.; Singh, B.K.; Dubey, B.; Tripathi, K.; Srivastava, V.; Shukla, D.N. Assessment of geochemical environment from study of river sediments in the middle stretch of river Ganga at Ghazipur, Buxar and Ballia Area. Proc. Natl. Acad. Sci. India Sect. B Biol. Sci. 2013, 83, 371-384. [CrossRef]

14. Caumette, G.; Koch, I.; Moriarty, M.; Reimer, K.J. Arsenic distribution and speciation in daphnia pulex. Sci. Total Environ. 2012, 432, 243-250. [CrossRef] [PubMed]

15. Müller, G. Schwermetalle in den sedimenten des Rheins-Veränderungen seit 1971. Umschan 1979, 79, 778-783.

16. Hakanson, L. An ecological risk index for aquatic pollution control. A sedimentological approach. Water Res. 1980, 14, 975-1001. [CrossRef]

17. Shuhaimi-Othman, M.; Yakub, N.; Ramle, N.A.; Abas, A. Comparative toxicity of eight metals on freshwater fish. Toxicol. Ind. Health 2015, 31, 773-782. [CrossRef]

18. Moore, D.W.; Farrar, D.; Altman, S.; Bridges, T.S. Comparison of acute and chronic toxicity laboratory bioassay endpoints with benthic community responses in field-exposed contaminated sediments. Environ. Toxicol. Chem. 2019, 38, 1784-1802. [CrossRef]

19. Peng, Z.Z.; Dan, X.; Yan, H.L.; Rong, H.T.; Ping, L.Y. Adsorption and desorption characteristics of cadmium in yellow soil and limestone soil. Guizhou Agric. Sci. 2015, 436, 83-86. (In Chinese)

20. Luo, K.; Liu, H.; Yu, E.; Tu, Y.; Gu, X.; Xu, M. Distribution and release mechanism of heavy metals in sediments of Yelang Lake by DGT. Stoch. Environ. Res. Risk Assess. 2020, 34, 793-805. [CrossRef]

21. Ling, H.S.; Lin, L.C.; Zhong, L.Y.; Guang, H.D.; Sheng, Y.Y.; Wei, Y.S. Geochemistry and environment of the cadmium in the soil and sediments at the surface of Guizhou province. Guizhou Geol. 2004, 4, 245-250. (In Chinese)

22. Ying, L.Z.; Zhong, C.Z.; Sheng, Y.G.; Ya, C.Z. Concentrations of 39 elements in stream sediment in different landscape zones of china. Earth Sci. Front. 2015, 225, 226-230. (In Chinese)

23. Fang, Y. Study on the Mass Balance of Mercury in Reservoirs at Different Evolution Stages in the Wujiang River Basin. Ph.D. Thesis, Southwest University, Chongqing, China, 2009. (In Chinese).

24. Wu, Y.G.; Xiong, Y.; Lin, C.X.; Yuan, L. The joint-biotoxicity effect of the different forms of phosphorus on heavy metal (Cu, Zn, Cd). Acta Sci. Circumstantiae 2006, 12, 2045-2051. (In Chinese)

25. Wu, Y.G.; Huang, J.G.; Yuan, L. Applying phototactic behaviour of Daphnia to monitor water quality. China Environ. Sci. 2004, 243, 336-339. (In Chinese)

26. Chinese Environmental Protection Administration (CEPA). Water Quality-Determination of the Acute Toxicity of Substance to Daphnia (Daphnia magna straus) (GB/T 13266-1991); China Standards Press: Beijing, China, 1991. (In Chinese)

27. Cairns, M.A.; Nebeker, A.V.; Gakstatter, J.H.; Griffis, W.L. Toxicity of copper-spiked sediments to freshwater invertebrates. Environ. Toxicol. Chem. 1984, 3, 435-445. [CrossRef]

28. ISO. Water Quality-Determination of the Inhibition of the Mortality of Daphnia magna Straus (Cladocera: Crustacea); Technical Report 6241; International Standards Organisation: Geneva, Switzerland, 1982.

29. Zhou, Y.X.; Zhang, Z.S. Test Method for Toxicity of Aquatic Organisms; Agricultural Press: Beijing, China, 1989; pp. 24-145. (In Chinese)

30. Daam, M.A.; Moutinho, M.F.; Espíndola, E.L.G.; Schiesari, L. Lethal toxicity of the herbicides acetochlor, ametryn, glyphosate and metribuzin to tropical frog larvae. Ecotoxicology 2019, 28, 707-715. [CrossRef]

31. Huan, L.Y.; Hong, L. Acute toxicity study of cadmium on scallops in the bay. Mar. Fish. Res. 2006, 6, 80-83. (In Chinese)

32. Wei, X.U.; Mu, F.H.; Sun, Y.T.; Cao, Z.Q. Effect of simulated ocean acidification on the acute toxicity of Cu and Cd to Tigriopus japonicus. Acta Ecol. Sin. 2014, 3414, 3879-3884. (In Chinese)

33. Qi, X.Z.; Jun, N.S.; Guo, T.X.; Jiang, Z.C. Calculation of toxicity coefficients of heavy metals in potential ecological hazard index method. Environ. Sci. Technol. 2008, 2, 112-115. (In Chinese) 
34. Qiang, M.Z.; Jiang, F.; Mi, W. Environmental Toxicology; China Environmental Science Press: Beijing, China, 2000; pp. 120-275. (In Chinese)

35. Liang, Y. Study on Biological Toxicity of Toxic Pollutants in Acid Wastewater of Coal Mines in Karst Areas. Ph.D. Thesis, Guizhou University, Guizhou, China, 2009. (In Chinese).

36. Yan, H.-J.; Zhang, H.-Y.; Shi, Y.-J.; Zhou, P.; Li, H.; Wu, D.-L.; Liu, L. Simulation on release of heavy metals Cd and Pb in sediments. Trans. Nonferrous Met. Soc. China 2021, 31, 277-287. [CrossRef]

37. National Standards of People's Republic of China. GB/T 21851-2008 (Chemicals-Adsorption-Desorption Using a Batch Equilibrium Method), GB/T 21805-2008 (Chemicals-Alga Growth Inhibition Test), GB/T 21830-2008 (Chemicals-Daphnia sp., Acute Immobilisation Test); Standardization Administration of the People's Republic of China: Beijing, China, 2008.

38. MEP. Environmental Quality Standards for Surface Water; GB 3838; Ministry of Environmental Protection of the People's Republic of China: Beijing, China, 2002. (In Chinese)

39. Zidour, M.; Boubechiche, Z.; Pan, Y.J.; Bialais, C.; Cudennec, B.; Grard, T.; Drider, D.; Flahaut, C.; Ouddane, B.; Souissi, S. Population response of the estuarine copepod eurytemora affinis to your bioaccumulation of trace metals. Chemosphere 2019, 220, 505-513. [CrossRef] [PubMed]

40. Jia, L.X.; Hui, P.Y.; Chao, L.C.; Hui, Q.Z. Acute toxicity study of copper and cadmium against Aspergillus. Fish. Sci. 2015, 3402, 95-99. (In Chinese)

41. Min, Z.Y.; Lei, Z.; Wen, Q.Y.; Hui, Z.B. Bio-toxicity of cadmium-spiked sediments to misgurnus anguillicaudatus. Asian J. Econ. 2011, 601, 80-86. (In Chinese)

42. Ling, P.; Ning, Z.J.; Zhen, C.Q.; Wei, H.; Ping, D. Effects of cadmium on antioxidant enzyme activity in gill of Mytilus coruscus and acute toxicity of cadmium on Mytilus coruscus. Environ. Sci. Technol. 2015, 38, 13-24. (In Chinese)

43. Xue, P.; Liang, H.X.; Han, C.S.; Jing, C.S.; Ping, Y.X. Single and joint acute toxicity of $\mathrm{Cd}+2$ and $\mathrm{Hg}+2$ to chinese mitten handed crab eriochersinensis. Fish. Sci. 2015, 34, 220-226. (In Chinese)

44. Zeng, Y.Y.; Lai, Z.N.; Yang, W.L.; Gao, Y.; Li, Y.F.; Pang, S.X. Toxicities and potential ecological effects of copper and cadmium to natural fish larvae and juveniles from the pearl river. Asian J. Econ. 2014, 91, 49-55. (In Chinese)

45. Yue, L.Y.; Lin, Z.Z.; Long, D.B.; Yang, F.J.; Mei, L.D. Acute toxicity of cadmium to allogynogenetic crucian carp. J. Fish. 2018, 3106, 36-39. (In Chinese)

46. Yang, L.; Xi, C.; Hui, Q.J. Acute toxic effect of cadmium on mosquito-eating fish (Gambusia affinis). J. Saf. Environ. 2015, 1503, 362-366. (In Chinese)

47. Long, W.R.; Zhi, M.G.; Qiang, Z.F. Safety Assessment and Acute toxicity of copper, cadmium and zinc to white clound mountain minnow tanichthys albonubes. Fish. Sci. 2006, 3, 117-120. (In Chinese)

48. Shou, S.; Lin, S.X.; Yan, W.G. Ecological toxicity of cadmium chloride on grass carp (Ctenopharyngodon idellus). J. Shenyang Ligong Univ. 2015, 34, 65-68, 72. (In Chinese)

49. Shuhaimi-Othman, M.; Yakub, N.; Umirah, N.S.; Abas, A. Toxicity of eight metals to malaysian freshwater midge larvae chironomus javanus (diptera, chironomidae). Toxicol. Ind. Health 2011, 27, 879-886. [CrossRef]

50. Martinez-Haro, M.; Moreira-Santos, M.; Marques, J.C.; Ribeiro, R. A short-term laboratory and in situ sediment assay based on the postexposure feeding of the estuarine isopod cyathura carinata. Environ. Res. 2014, 134, 242-250. [CrossRef]

51. Bielmyer-Fraser, G.K.; Harper, B.; Picariello, C.; Albritton-Ford, A. The influence of salinity and water chemistry on acute toxicity of cadmium to two euryhaline fish species. Comp. Biochem. Physiol. Part-C Toxicol. Pharmacol. 2018, 214, 23-27. [CrossRef]

52. Shuhaimi-Othman, M.; Nadzifah, Y.; Nur-Amalina, R.; Umirah, N.S. Deriving freshwater quality criteria for copper, cadmium, aluminum and manganese for protection of aquatic life in Malaysia. Chemosphere 2013, 90, 2631-2636. [CrossRef]

53. Wigginton, A.J.; Birge, W.J. Toxicity of cadmium to six species in two genera of crayfish and the effect of cadmium on molting success. Environ. Toxicol. Chem. 2007, 26, 548-554. [CrossRef] [PubMed]

54. Shaw, J.R.; Colbourne, J.K.; Glaholt, S.P.; Turner, E.; Folt, C.L.; Chen, C.Y. Dynamics of cadmium acclimation in daphnia pulex: Linking fitness costs, cross-tolerance, an hyper-inaction of metallothionein. Environ. Sci. Technol. 2019, 53, 14670-14678. [CrossRef]

55. Shaw, J.R.; Colbourne, J.K.; Davey, J.C.; Glaholt, S.P.; Hampton, T.H.; Chen, C.Y.; Folt, C.L.; Hamilton, J.W. Gene response profiles for daphnia pulex exposed to the environmental stressor cadmium reveals novel crustacean metallothioneins. BMC Genom. 2007, 8, 1-19. [CrossRef] [PubMed]

56. Yang, J.; Yuan, L.; Tang, Y. Monitoring sodium pentachlorophenate and cadmium in aquatic solutions by phototactic behavior of Daphnia carinata clone. Acta Sci. Circumstantiae 2006, 266, 1011-1015. (In Chinese)

57. Niyogi, S.; Wood, C.M. Biotic ligand model, a flexible tool for developing site-specific water quality guidelines for metals. Environ. Sci. Technol. 2004, 38, 6177-6192. [CrossRef]

58. Dallinger, R.; Höckner, M. Evolutionary concepts in ecotoxicology: Tracing the genetic background of differential cadmium sensitivities in invertebrate lineages. Ecotoxicology 2013, 22, 767-778. [CrossRef]

59. Tan, Q.G.; Wang, W.X. Acute toxicity of cadmium in daphnia magna under different calcium and PH conditions: Importance of influx rate. Environ. Sci. Technol. 2011, 45, 1970-1976. [CrossRef]

60. Chen, S.; Nichols, K.M.; Poynton, H.C.; Sepúlveda, M.S. MicroRNAs are involved in cadmium tolerance in daphnia pulex. Aquat. Toxicol. 2016, 175, 241-248. [CrossRef] [PubMed]

61. Colbourne, J.K.; Pfrender, M.E.; Gilbert, D.; Thomas, W.K.; Tucker, A.; Oakley, T.H.; Tokishita, S.; Aerts, A.; Arnold, G.J.; Basu, M.K.; et al. The ecoresponsive genome of daphnia pulex. Science 2011, 331, 555-561. [CrossRef] [PubMed] 
62. Wen-Hong, F.; Tang, G.; Zhao, C.M.; Duan, Y.; Zhang, R. Metal accumulation and biomarker responses in daphnia magna following cadmium and zinc exposure. Environ. Toxicol. Chem. 2009, 28, 305-310.

63. CMEE (China Ministry of Ecology and Environment). Chinese Soil Environmental Quality: Risk Control Standard for Soil Contamination of Agricultural Land (GB 15618-2018); China Environmental Science Press: Beijing, China, 2018. (In Chinese)

64. Vukosav, P.; Mlakar, M.; Cukrov, N.; Kwokal, Ž.; Pižeta, I.; Pavlus, N.; Špoljarić, I.; Vurnek, M.; Brozinčević, A.; Omanović, D. Heavy metal contents in water, sediment and fish in a karst aquatic ecosystem of the plitvice lakes national park (Croatia). Environ. Sci. Pollut. Res. 2014, 21, 3826-3839. [CrossRef]

65. Liu, P.; Zheng, C.; Wen, M.; Luo, X.; Wu, Z.; Liu, Y.; Chai, S.; Huang, L. Ecological risk assessment and contamination history of heavy metals in the sediments of Chagan Lake, Northeast China. Water 2021, 13, 894. [CrossRef]

66. Shi, J.B.; Wu, Y.G.; Yan, L.; Liu, F.; Yu, Y.H. The acute biological toxicity of $\mathrm{Pb}$ and Zn caused by zinc oxide industrial waste in karst areas in Guizhou. Guizhou Agric. Sci. 2009, 37, 89-92. (In Chinese)

67. Xiong, X.Q.; Luo, S.; Wu, B.L.; Wu, B.L.; Wang, J.W. Acute toxicity of cadmium and copper to gobiocypris rarus under different water hardness. Asian J. Econ. 2016, 11, 316-322. (In Chinese)

68. Ali, H.; Khan, E.; Ilahi, I. Environmental chemistry and ecotoxicology of hazardous heavy metals: Environmental persistence, toxicity, and bioaccumulation. J. Chem. 2019, 2019. [CrossRef]

69. Lim, K.Y.; Zakaria, N.A.; Foo, K.Y. Geochemistry pollution status and ecotoxicological risk assessment of heavy metals in the Pahang river sediment after the high magnitude of flood event. Hydrol. Res. 2021, 52, 107-124. [CrossRef]

70. Tian, K.; Wu, Q.; Liu, P.; Hu, W.; Huang, B.; Shi, B.; Zhou, Y.; Kwon, B.O.; Choi, K.; Ryu, J.; et al. Ecological risk assessment of heavy metals in sediments and water from the coastal areas of the Bohai Sea and the Yellow Sea. Environ. Int. 2020, 136, 105512. [CrossRef] [PubMed] 